\title{
EVALUATION OF HISTOPATHOLOGY OF ENDOMETRIUM IN PERIMENOPAUSAL ABNORMAL UTERINE BLEEDING
}

\author{
Vani Isukapalli', Koppala Bhavani², Padmavathi Bai Desavathu
}

${ }_{1}^{1}$ Associate Professor, Department of Obstetrics and Gynaecology, Andhra Medical College, King George Hospital, Visakhapatnam. ${ }^{2}$ Assistant Professor, Department of Obstetrics and Gynaecology, Andhra Medical College, King George Hospital, Visakhapatnam. ${ }^{3}$ Postgraduate Student, Department of Obstetrics and Gynaecology, Andhra Medical College, King George Hospital, Visakhapatnam.

\section{ABSTRACT}

\section{BACKGROUND}

Abnormal Uterine Bleeding (AUB) is the most common presenting symptom in Gynaecology outpatient department. Endometrial sampling could be effectively used as the first diagnostic step in abnormal uterine bleeding in perimenopausal age group. This study was done to evaluate histopathology of endometrium for identifying the endometrial causes of AUB in perimenopausal age.

The main objective of the present study is to evaluate the histopathology of endometrium and to identify the hyperplasia of endometrium or endometrial carcinoma.

\section{MATERIALS AND METHODS}

The present study was conducted in the Department of Obstetrics and Gynaecology, King George Hospital, Visakhapatnam who presented with abnormal uterine bleeding for a period of one year, i.e. March 2015 to March 2016 in the age group of 40 to 55 years. Endometrial tissue is obtained by dilatation and curettage or endometrial biopsy or fractional curettage sent to pathology and histopathology of endometrium evaluated. A total of 200 patients are taken into the present study and histopathology of endometrium obtained and evaluated.

\section{RESULTS}

The most common histopathology of endometrium is proliferative endometrium followed by secretory endometrium. Simple hyperplasia is observed in $3.5 \%$ of patients. Simple hyperplasia with atypia in $0.5 \%$. Complex hyperplasia with atypia observed in $0.5 \%$ of patients.

\section{CONCLUSION}

The histopathology of endometrium plays a key role in evaluation and further management of abnormal uterine bleeding.

\section{KEYWORDS}

Abnormal Uterine Bleeding, Histopathology of Endometrium.

HOW TO CITE THIS ARTICLE: Isukapalli V, Bhavani K, Desavathu PB. Evaluation of histopathology of endometrium in perimenopausal abnormal uterine bleeding. J. Evolution Med. Dent. Sci. 2017;6(19):1512-1514, DOI: 10.14260/Jemds/2017/332

\section{BACKGROUND}

Abnormal uterine bleeding is one of the most common health problems of women. It affects about $20 \%$ of women of reproductive age group and accounts for two-thirds of all hysterectomies. The incidence of menstrual irregularities increases in advancing age group. The commonest age group presenting with abnormal uterine bleeding is perimenopausal age, i.e. 40 to 55 years. $1,2,3,4,5,6,7$ Abnormal uterine bleeding is defined as bleeding that is excessive and occurs outside of normal cyclic menstruation.

\begin{tabular}{|c|c|}
\hline Menstrual Cycle Frequency & 24 - 38 Days \\
\hline Cycle Variation from Cycle to Cycle & 2 - 20 Days \\
\hline Duration of Flow & 4 - 8 Days \\
\hline Volume of Flow & $4-80 \mathrm{~mL}$ \\
\hline $\begin{array}{l}\text { Table 1. Parameters for Norm } \\
\text { Cycles in Women of Reprod }\end{array}$ & $\begin{array}{l}\text { nstrual } \\
\text { Age }\end{array}$ \\
\hline
\end{tabular}

Financial or Other, Competing Interest: None.

Submission 27-12-2016, Peer Review 18-02-2017,

Acceptance 24-02-2017, Published 06-03-2017.

Corresponding Author:

Dr. Padmavathi Bai Desavathu,

Gynaec Institute,

King George Hospital,

Visakhapatnam.

E-mail: paddudesavathu@gmail.com

DOI: $10.14260 /$ jemds $/ 2017 / 332$

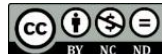

Data from Fraser IS, Critchley HO, Munro MG. Abnormal uterine bleeding: getting our terminology straight. Curr Opin Obstet Gynaecol 2007;591-595.

Abnormal uterine bleeding includes both dysfunctional uterine bleeding and bleeding from structural causes like fibroids, polyps and endometrial carcinoma.

Federation of International of Gynaecologists and Obstetricians (FIGO) in 2011 came with the new nomenclature of AUB. This classification is named PALMCOEIN system. ${ }^{8}$

It stands for polyp, adenomyosis, leiomyoma, malignancy, coagulopathy, ovulatory dysfunction, endometrium, iatrogenic and non-classified. The first four are related to the structural uterine abnormalities that can be measured visually by imaging modalities and by histopathological study. The others are non-structural and attributed to coagulation disorders and hormonal dysfunction. $\mathrm{N}$ stands for no cause detected.

Dysfunctional uterine bleeding is defined as abnormal uterine bleeding without any demonstrable organic cause. It may be anovulatory characterised by irregular, unpredictable bleeding or ovulatory resulting in heavy but regular periods.

A detailed history, pelvic examination along with transvaginal scan, the cause of bleeding is established in only $50 \%-60 \%$ of the cases.

The major challenge to address is to allay the worries about possible uterine cancer, while treating a lady for AUB in perimenopausal age group. Histological examination of 
endometrium therefore remains the cornerstone for AUB. Dilatation and Curettage is the mainstay of endometrial sampling and also allows fractional curettage with separate sampling of both the endometrial and endocervical tissue. Hysteroscopy has replaced blind curettage, as the uterine cavity can be observed and the area in question can be curetted. Although hysteroscopic evaluation is the gold standard for AUB, endometrial curettage continues to be performed in public hospital and taken into the study.

\section{Aims and Objectives}

The main goal in evaluation of abnormal uterine bleeding in perimenopausal women is to exclude endometrial hyperplasia with atypia and endometrial carcinoma.

Evaluation of endometrium involves two goals -

- To know accurate reasons for bleeding.

- To rule out endometrial carcinoma or potential for cancer in future.

\section{MATERIALS AND METHODS}

The present study is retrospective age specific analysis of perimenopausal women between 40 - 55 years presenting with abnormal uterine bleeding for a period of one year, i.e. March 2015 to March 2016 at the Department of Obstetrics and Gynaecology, King George Hospital, Visakhapatnam.

Endometrial tissue obtained by dilatation and curettage, endometrial biopsy, fractional curettage has been sent for pathological examination.

\section{RESULTS}

A total of 200 cases of perimenopausal women between 40 to 55 years presenting with abnormal uterine bleeding are evaluated and the histopathology of endometrium collected and analysed.

\begin{tabular}{|c|c|}
\hline Age (Years) & No. of Cases \\
\hline $40-45$ & $170(85 \%)$ \\
\hline $45-50$ & $20(10 \%)$ \\
\hline $50-55$ & $10(5 \%)$ \\
\hline Table 2. Age Wise Distribution of Cases \\
\hline
\end{tabular}

In the present study majority of the patients are between 40 - 45 years, may be due to the higher incidence of abnormal uterine bleeding in perimenopausal age group.

\section{AGEWISE DISRIBUTION OF CASES}

$10 \%$ $5 \%$

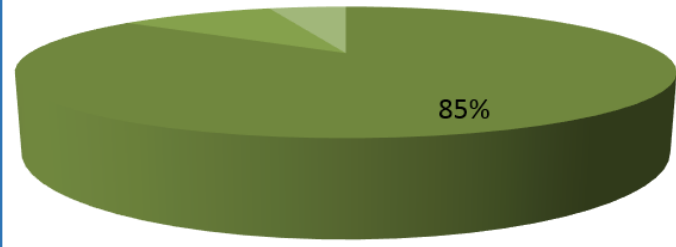

40-45

45-50

- 50-55

Figure 1. Age Wise Distribution of Cases

\begin{tabular}{|c|c|}
\hline $\begin{array}{c}\text { Histopathology of } \\
\text { Endometrium }\end{array}$ & Total No. of Cases \\
\hline Proliferative Endometrium & $120(60 \%)$ \\
\hline Secretory Endometrium & $62(31 \%)$ \\
\hline Pill-Induced Endometrium & $3(1.5 \%)$ \\
\hline Irregular Ripening & $2(1 \%)$ \\
\hline Irregular Shedding & 0 \\
\hline Endometritis & $4(2 \%)$ \\
\hline \multicolumn{2}{|c|}{ Table 3. Histopathology of Endometrium } \\
\hline
\end{tabular}

In the above table, the proliferative endometrium (85\%) is the most common histopathology in perimenopausal abnormal bleeding and secretory endometrium is the second most common histopathology observed in the present study.

\begin{tabular}{|c|c|c|}
\hline Histopathology of Endometrium & No. of Cases & (\%) \\
\hline $\begin{array}{c}\text { Simple Hyperplasia without Atypia } \\
\text { Complex Hyperplasia without } \\
\text { Atypia }\end{array}$ & $0(3.5 \%)$ & \multirow{2}{*}{$(3.5 \%)$} \\
\hline $\begin{array}{c}\text { Simple Hyperplasia } \\
\text { with Atypia }\end{array}$ & $1(0.5 \%)$ & \multirow{2}{*}{$(1 \%)$} \\
\hline $\begin{array}{c}\text { Complex Hyperplasia } \\
\text { with Atypia }\end{array}$ & $1(0.5 \%)$ & \\
\hline \multicolumn{2}{|c|}{$\begin{array}{c}\text { Table 4. Distribution of Cases } \\
\text { with Endometrial Hyperplasia }\end{array}$} \\
\hline
\end{tabular}

In the present study, hyperplasia without atypia was seen in $3.5 \%$ of cases and hyperplasia with atypia was seen in $1 \%$ of cases.

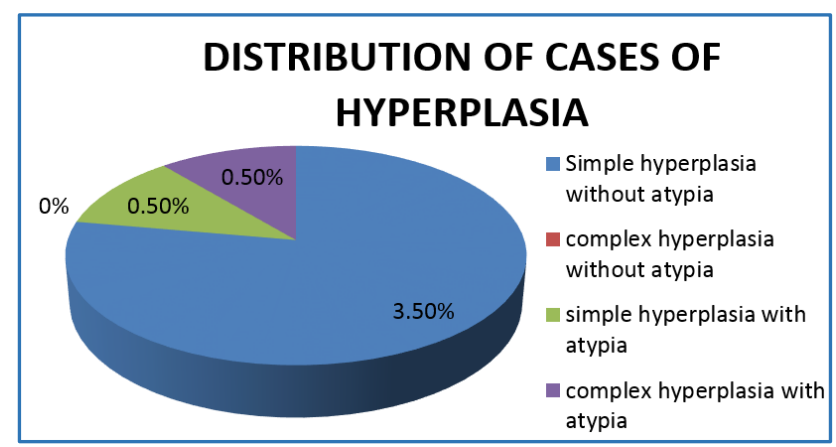

Figure 2. Distribution of Hyperplasia Cases

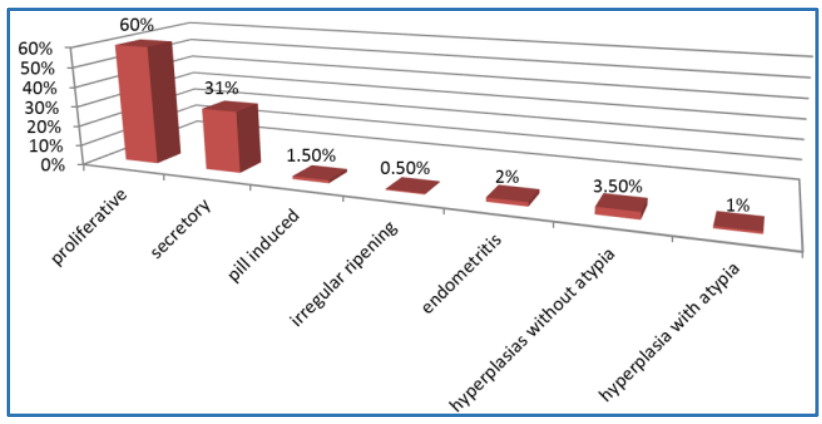

Figure 3. HPE of Endometrium Wise Distribution of Cases

\begin{tabular}{|c|c|}
\hline Type of Hyperplasia & $\begin{array}{c}\text { Progression to } \\
\text { Cancer (\%) }\end{array}$ \\
\hline Simple (Cystic without Atypia) & 1 \\
\hline Complex (Adenomatous without \\
Atypia) & 3 \\
\hline Simple (Cystic with Atypia) & 8 \\
\hline Complex (Adenomatous with Atypia) & 29 \\
\hline Table 5. Progression Rate of Different Hyperplasia \\
\hline
\end{tabular}

\begin{tabular}{|c|c|c|c|c|}
\hline $\begin{array}{c}\text { Type of } \\
\text { Hyperplasia }\end{array}$ & $\begin{array}{c}\text { Pilli } \\
\text { et al14 }\end{array}$ & $\begin{array}{c}\text { Vakiani } \\
\text { et al15 }\end{array}$ & $\begin{array}{c}\text { Bolde SA } \\
\text { et al16 }\end{array}$ & $\begin{array}{c}\text { Present } \\
\text { Study }\end{array}$ \\
\hline $\begin{array}{c}\text { Simple Hyperplasia } \\
\text { without Atypia }\end{array}$ & $73 \%$ & $71 \%$ & $85 \%$ & $3.5 \%$ \\
\hline $\begin{array}{c}\text { Complex } \\
\text { Hyperplasia } \\
\text { without Atypia }\end{array}$ & $27 \%$ & $26.6 \%$ & $12 \%$ & $0 \%$ \\
\hline $\begin{array}{c}\text { Hyperplasia } \\
\text { with Atypia }\end{array}$ & $0 \%$ & $1.71 \%$ & $3 \%$ & $1 \%$ \\
\hline
\end{tabular}




\section{DISCUSSION}

Abnormal uterine bleeding accounts for $25 \%$ of Gynaecological surgeries and $20 \%$ of outpatient visits. ${ }^{9}$

The occurrence of menstrual disorders increases with advancing age group. In the present study perimenopausal age group is taken into consideration as it is the most common age group presenting with uterine bleeding $1,2,3,4,5,6,7$ and also meticulous evaluation is required in these age group, as there is increased incidence of hyperplasia is more common. Early evaluation of these patients helps in reduction of endometrial carcinoma.

In the present study, the commonest age group presenting with excessive bleeding is $40-45$ years (Table 2). Similar incidence is reported in Yusuf et al $^{10}$ and Muzaffar et al in their study of endometrium. Bhoomika Dadhania and Gauravi Dhruva et al ${ }^{11}$ in their study on endometrium in dysfunctional uterine bleeding observed the most common age was 41 - 50 years constituting $40.6 \%$ of the patients. Perimenopause is defined by the World Health Organisation as 2 to 8 years preceding menopause and 1 year after the last menses. ${ }^{9}$ The reason for increased incidence of abnormal uterine bleeding in this age group may be due to the fact that these patients are in climacteric period. As women approaches menopause, cycles shorten and often become intermittently anovulatory due to decrease in the number of ovarian follicles and the estradiol levels. 12

The reason for appropriate evaluation of endometrium in this age group is important due to the fact that the patients are evaluated much earlier and treated appropriately decreasing the incidence of chances of endometrial hyperplasia progressing to endometrial carcinoma in later age group.

In the present study, the most common endometrial histopathology was proliferative endometrium followed by secretory endometrium.

The cause of bleeding in proliferative phase is anovulatory cycles, such cases shows progressive rise of oestrogen to comparatively high levels, which is then followed by sudden fall in oestrogen due to feedback inhibition of pituitary or of FSH secretion and bleeding results and the cause of bleeding in secretory endometrium is ovulatory dysfunctional uterine bleeding. The main defect is in the control of processes regulating the volume of blood lost during menstrual breakdown of endometrium.

The classification used by World Health Organisation and International Society of Gynaecological Pathologists designates four different types of hyperplasia with varying malignant potential. Hyperplasia is classified as simple or complex based on the presence or absence of architectural abnormalities, such as glandular complexity and crowding. Most important, these are further designated as atypical if there demonstrate cytology and/or nuclear atypia.

Endometrial hyperplasia is precursors of endometrial carcinoma. In the present study, endometrial hyperplasia without atypia was seen in $3.5 \%$ and with atypia in $1 \%$ of cases (Table 4).

The incidence of hyperplasia in various studies is as follows. Endometrial hyperplasia and carcinomas are more evident in perimenopausal and postmenopausal women. The routine non-invasive investigations for AUB include complete blood picture, platelet count, prothrombin time, Activated Partial Thromboplastin Time (APTT), liver function test to rule out any coagulation and secretory disorders. In women of reproductive age group, urine HCG is to be evaluated to rule out pregnancy. On ruling out these causes, gynaecologist turn to imaging studies such as pelvic ultrasound, transvaginal ultrasound and then tissue sampling. Dilatation and curettage can be diagnostic and therapeutic procedure. ${ }^{12}$ The sensitivity of endometrial biopsy for detection of endometrial abnormalities has been reported to be as high as $96 \%{ }^{9,12}$ So a thorough histopathological and clinical correlation is mandatory in cases of abnormal uterine bleeding above the age of 40 years to find organic lesions. Careful screening can detect early cancer of endometrium, which has excellent prognosis and will help in further management.

\section{CONCLUSION}

Histopathological examination of endometrium is a major diagnostic tool in evaluation of abnormal uterine bleeding in perimenopausal abnormal uterine bleeding and a specific diagnosis could help the physician to plan therapy for successful management of abnormal uterine bleeding.

\section{REFERENCES}

[1] Jyotsana KM, Sharma S. Role of hysteroscopy and laparoscopy in evaluation of abnormal uterine bleeding. JK Sci 2004;6:23-7.

[2] Muzaffar M, Akhtar KA, Yasmin S, et al. Menstrual irregularities with excessive blood loss: a clinicopathological correlation. J Pak Med Assoc 2005;55(11):486-9.

[3] Doraiswami S, Johnson T, Rao S, et al. Study of endometrial pathology in abnormal uterine bleeding. J Obstet Gynaecol India 2011;6(4):426-30.

[4] Bhosle A, Fonseca M. Evaluation and histopathological correlation of abnormal uterine bleeding in perimenopausal women. Bombay Hosp J 2010;52:6972.

[5] Khan S, Hameed S, Umber A. Histopathological pattern of endometrium on diagnostic $\mathrm{D}$ and $\mathrm{C}$ in patients with abnormal uterine bleeding. Annals 2011;17:166-70.

[6] Sinha P, Rekha PR, Konapur PG, et al. Pearls and pitfalls of endometrial curettage with that of hysterectomy in DUB. J Clin Diagn Res 2011;5:1199202.

[7] Azim P, Khan MM, Sharif N, et al. Evaluation of abnormal uterine bleeding on endometrial biopsies. ISRA Medical J 2011;3(3):84-8.

[8] Munro MG, Critchley HO, Fraser IS. The FIGO classification of causes of abnormal uterine bleeding in the reproductive years. Fertil Steril 2011;95(7):2204-8.

[9] Goldstein SR. Menorrhagia and abnormal bleeding before the menopause. Best Pract Res Clin Obstet Gynaecol 2004;18(1):59-69.

[10] Yusuf NW, Nadeem R, Yusuf AW et al. Dysfunctional uterine bleeding. A retrospective clinicopathological study over 2 years. Pak J Obstet Gynecol 1996;9:27-30.

[11] Dadhania B, Dhruva G, Agravat A, et al. Histopathological study of endometrium in dysfunctional uterine bleeding. Int J Res Med 2013;2(1):20-4.

[12] Mazur MT, Kurman RJ. Normal endometrium and infertility evaluation. In: Mazur MT, Kurman RJ, eds. Diagnosis of endometrial biopsies and curettings: a practical approach. 2nd edn. New York: Springer Verlag 2005:7-33. 